\title{
Close Range Photogrammetry in the Survey of the Coastal Area Geoecological Conditions (on the Example of Portugal)
}

\author{
Nino Chikhradze ${ }^{1,2}$ *, Renato Henriques ${ }^{3}$, Mikheil Elashvili ${ }^{2}$, Giorgi Kirkitadze ${ }^{2}$, Zurab Janelidze $^{2}$, \\ Nana Bolashvili ${ }^{1}$, George Lominadze ${ }^{1}$
}

${ }^{1}$ Vakhushti Bagrationi Institute of Geography, Ivane Javakhishvili Tbilisi State University, Tbilisi, Georgia

${ }^{2}$ School of Natural Sciences and Engineering, Ilia State University, Tbilisi, Georgia

${ }^{3}$ Department of Earth Sciences, School of Sciences, University of Minho, Braga, Portugal

Email address:

nino.chikhradze.1@iliauni.edu.ge (N. Chikhradze),nchikhradze@yahoo.com (N. Chikhradze)

\section{To cite this article:}

Nino Chikhradze, Renato Henriques, Mikheil Elashvili, Giorgi Kirkitadze Zurab Janelidze, Nana Bolashvili, George Lominadze. Close Range Photogrammetry in the Survey of the Coastal Area Geoecological Conditions (on the Example of Portugal). Earth Sciences. Special Issue: Modern Problems of Geography and Anthropology. Vol. 4, No. 5-1, 2015, pp. 35-40. doi: 10.11648/j.earth.s.2015040501.17

\begin{abstract}
Close range digital photogrammetry, which involves the application of unmanned aerial vehicle (UAV), has been used in a growing number of diverse applications across different scientific disciplines. Our objective was to use the mentioned method in the survey of the contemporary geoecological conditions of the coastal area on the example of Portuguese northwest coastal zone. The coastal zone can be subdivided into two geomorphological sectors: Sector 1, between the Minho River and the town of Espinho, where the coastal segments consist of estuaries, sandy and shingle beaches with rocky outcrops, and Holocene dune systems. The estuaries and the foredunes in particular are very degraded by human activities; and Sector 2, between Espinho and the Mondego Cape, where coastal lagoons and Holocene dune systems occur. We chose two beaches for surveying - Aguçadoura and Ramalha to which the drone swinglet CAM took the photos. We used the ground control software eMotion 2 to plan the flights over the study area and controlled the drone's trajectory during flight. After processing the obtained images in the program of AgisoftPhotoscanPro, we generated the 2D orthophotos and 3D digital elevation models (DEM) of the research sections. At this stage of study we derived the above product without using the ground control points, or we used only the camera GPS data. Based on these models the compilation of the large-scale maps of high resolution $(1 \mathrm{~cm}-5 \mathrm{~cm})$ will be possible in the GISs for monitoring and management of the geoecological state of the mentioned beaches in case to precise the $\mathrm{x}, \mathrm{y}$ and $\mathrm{z}$ values of the models with the geodetic device of Differential GPSs in the selected ground control points (GCP).
\end{abstract}

Keywords: Unmanned Aerial Vehicle, Beach, Orthophoto, Digital Elevation Model, Accuracy

\section{Introduction}

Vast amounts of remote sensing data are acquired daily all over the globe from satellites, from manned or unmanned airborne platforms, and from the ground. (Markelin, 2013). Close range digital photogrammetry, which involves the application of unmanned aerial vehicle (UAV) photogrammetry, has been used in a growing number of diverse applications across different scientific disciplines. Early applications of UAVs included cultural heritage and archaeology, mainly for the documentation and modeling of monuments, buildings and landscapes [2].

However, the reference to the use of UAVs for coastal monitoring is still scarce in the scientific literature [3].

Our objective was to use the method of close range digital photogrammetry in the survey of the contemporary geoecological conditions of the coastal area on the example of Portuguese north-west coastal zone and to generate the 2D orthophotos and 3D digital elevation models (DEM) of the study area in order to use them in the monitoring and management of the geoecological state of the study area.

Coastal zones are naturally dynamic and mobile systems exposed to natural factors (river flows, waves and storms) as well as human interventions that continuously reshape their morphology. Erosion phenomena related to extreme weather events and sediment scarcity are common, threatening 
buildings and infrastructures, as well as beaches, ecosystems and valuable wetland; conditions that pose challenges to coastal security and defense. Regular monitoring of coastal areas, assessment of their morphodynamics and identification of the processes influencing sediment transport are thus increasingly important for a better understanding of changes and evolutionary trends in coastal systems [4].

\section{Regional Setting}

The Portuguese coastline is mostly low and sandy. In the middle part of the country and the extreme south-west of it, is not high, but steep and abrupt [5].

The coastal landscape can be considered as a non-renewable natural resource, having a particular geomorphology. The actual coastal morphology of Portugal has been originated in a recent geological time (Pleistocene, Holocene) as well by more recent natural and human actions [6].

The coastal zone of northwest Portugal can be subdivided into two geomorphological sectors: Sector 1, between the Minho River and the town of Espinho, where the coastal segments consist of estuaries, sandy and shingle beaches with rocky outcrops, and Holocene dune systems (foredunes and some migrating dunes with blow-outs). The estuaries and the foredunes in particular are very degraded by human activities. Sector 2, between Espinho and the Mondego Cape, where coastal lagoons and Holocene dune systems (foredunes, parabolic and transverse dunes) occur [7]. We chose the two beaches for surveying - Aguçadoura and Ramalha beaches, which fall into the Sector 1 (Figure 1, Figure 2).

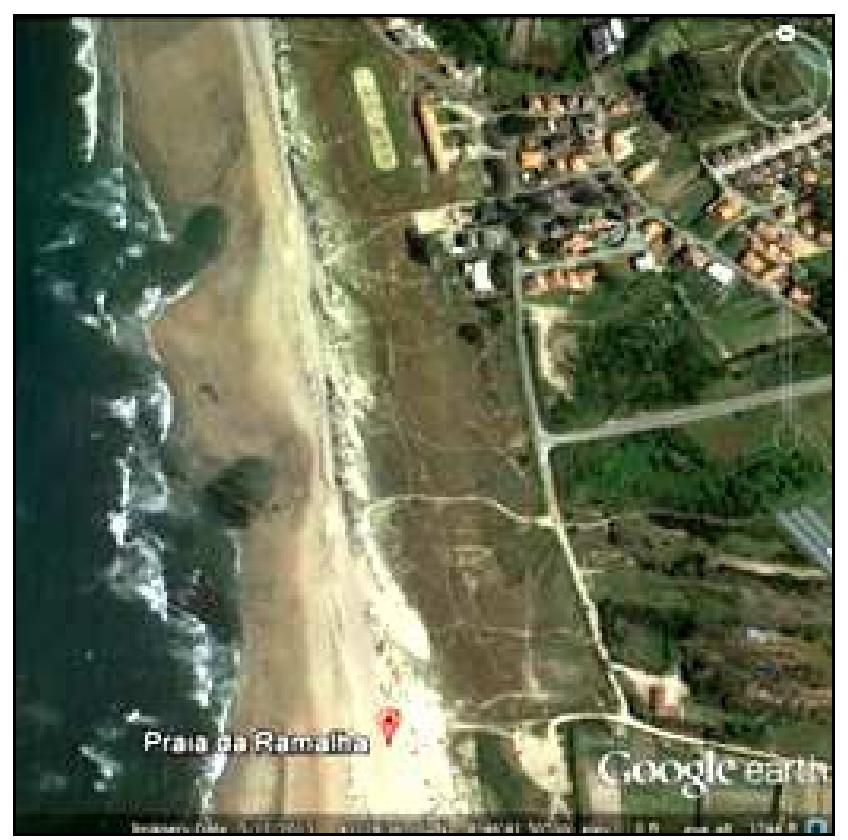

Figure 1. Ramalia beach (Source: Google Earth Pro image, 2013).

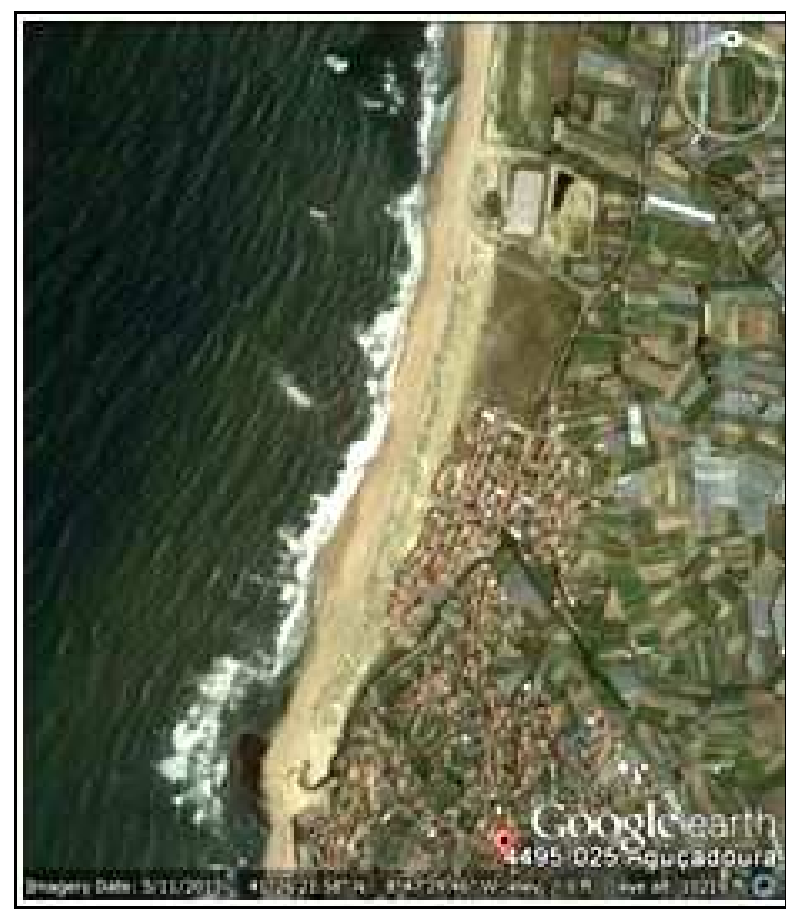

Figure 2. Aguçadoura beach (Source: Google Earth Pro image, 2013).

The Aguçadoura and Ramalha beaches are the famous tourist destinations. located in the city's rural outskirts, Aguçadoura is the best surfing beach of the city of Póvoa de Varzim, with a large dune area, making it the longest beach in Póvoa [8]. Ramalha beach also displays a very extensive sand and well preserved dune system [9].

\section{Material and Methods}

We conducted several field works. Goals of our field works were to study the present geoecological conditions of the Portuguese north-west coastal zone by using the traditional surveying methods and by applying the latest research method of close-range digital photogrammetry.

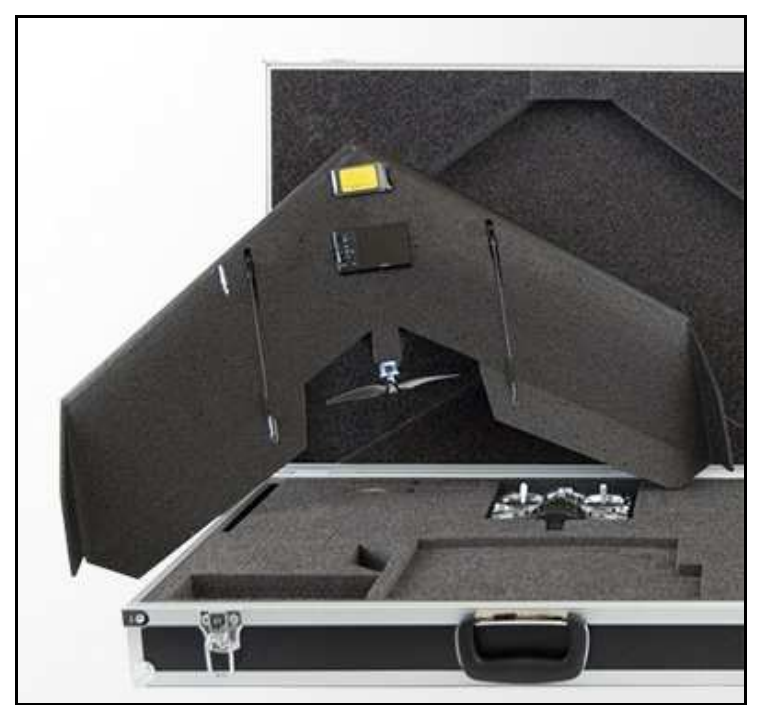

Figure 3. The swinglet CAM with the camera Canon Ixus 220 HS onboard. 
We conducted our mission by the UAV swinglet CAM (Figure 3), which has a camera Canon Ixus 220 HS onboard, with a sensor of 12 Mpixels.

The swinglet CAM is a professional GIS tool that offers all we need to create geo-referenced aerial imagery and quick orthomosaics. It is very light and easy to take-off and landing; the drone can be launched by hand and no additional equipment is required. It flies and lands autonomously with the built-in autopilot and the $2.4 \mathrm{GHz}$ USB radio modem. With this radio modem and the ground antenna (Figure 4) the radio link can be established.

We used:

a) the ground control software eMotion 2 to plan the flights (Figure 5) in the laptop over the study area and controlled the drone's trajectory during flights;

b) the software Postflight Terra LT to associate each aerial image with the position and orientation of the camera (also known as geotag). It can also be used to quickly check image overlap and to calculate a rough orthomosaic while in the field [10];

c) the software Agisoft PhotoScan Professional to generate the orthophotos and digital elevation models; and d) the software of QGIS and ArcGIS to visualize and analyze them.

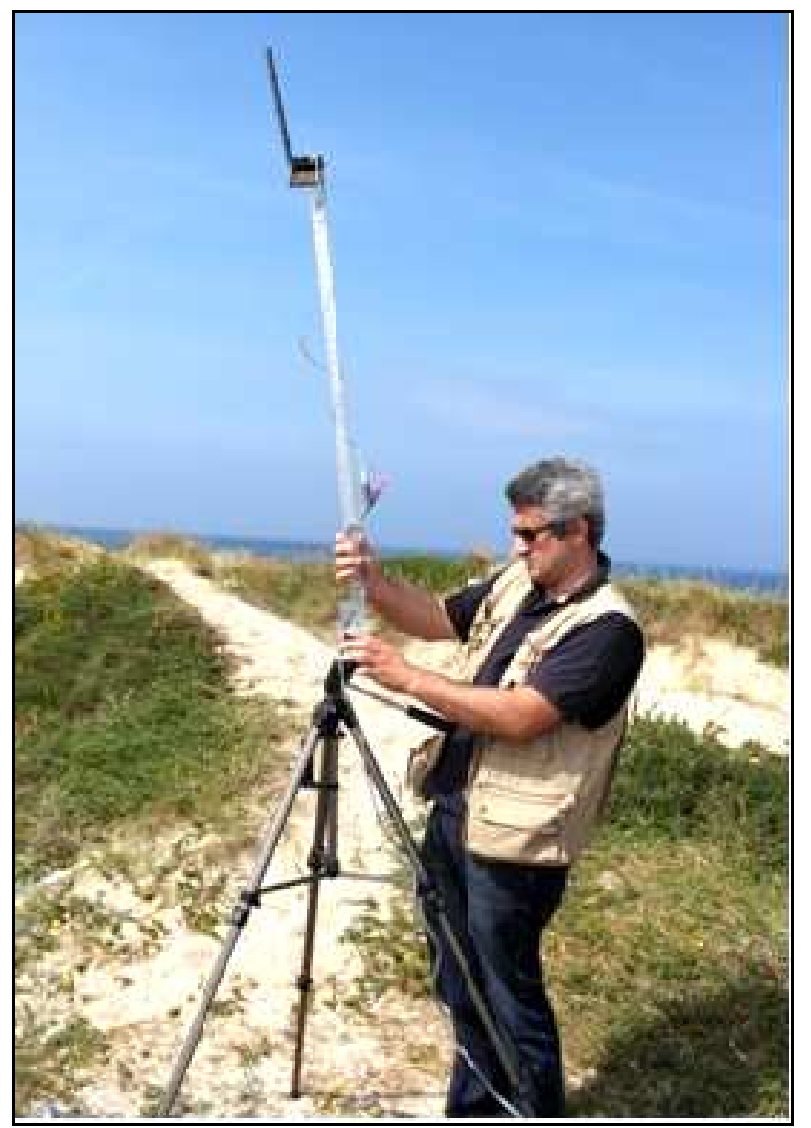

Figure 4. Renato Henriques mounting the ground antenna (Photo by N.Chikhradze, 2014).

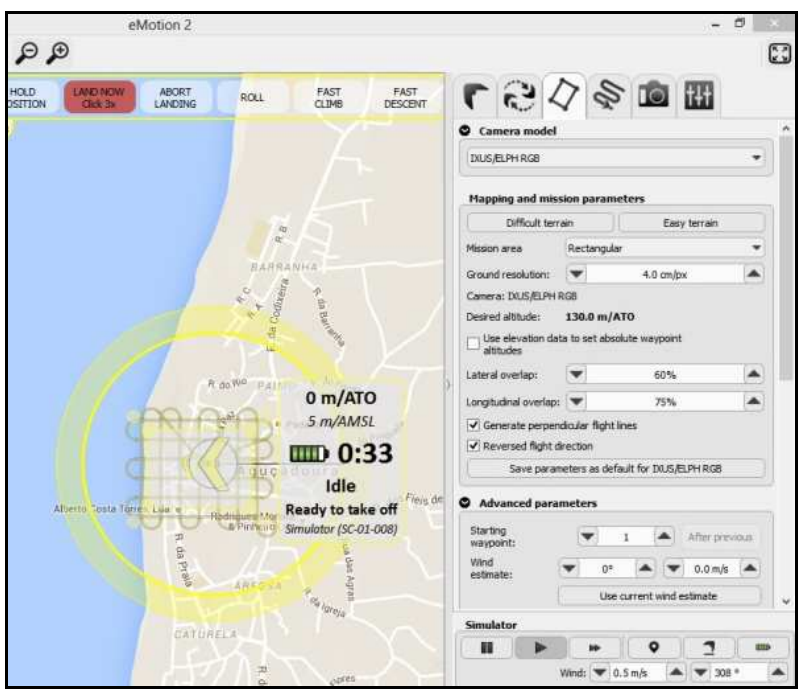

Figure 5. Software eMotion 2 for planning missions.

\section{Results and Discussions}

According to the complete workflow of the Agisoft PhotoScan Professional we generated the 2D georeferenced orthopotos and 3D digital elevation models of Aguçadoura and Ramalha beaches (Fig. 6, 7, 8,9).

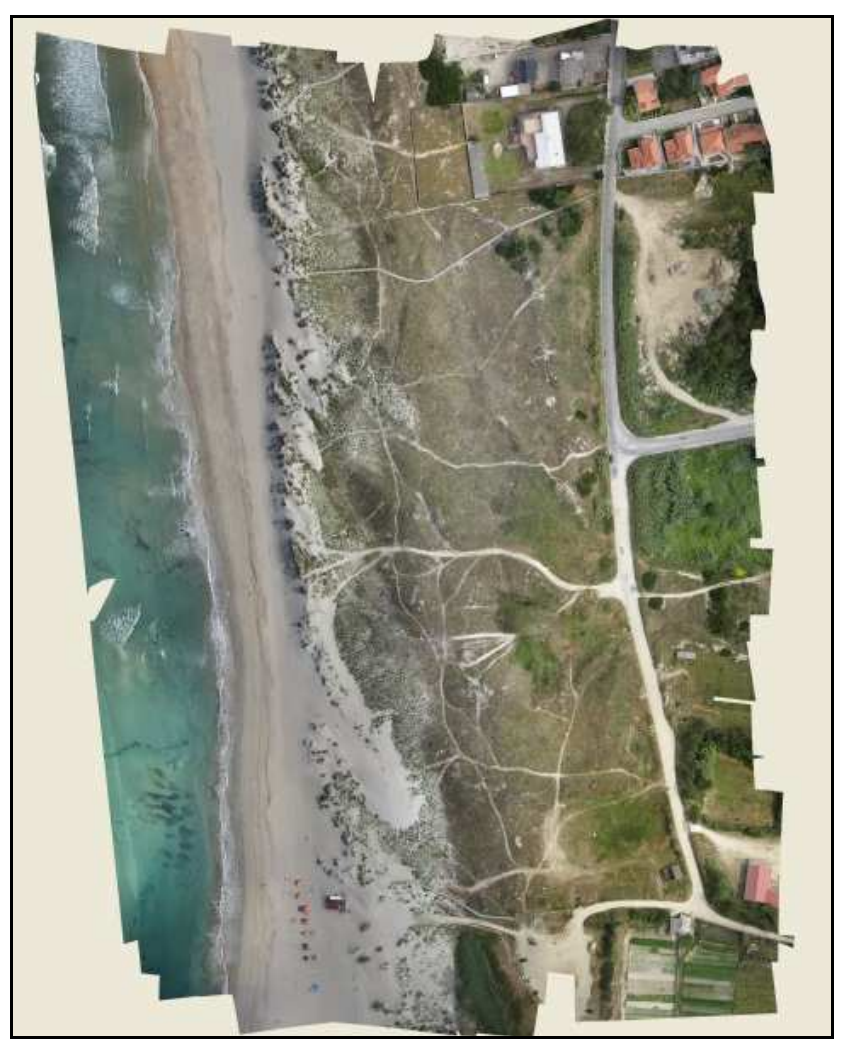

Figure 6. Orthophoto of the Ramalha beach (2014). 


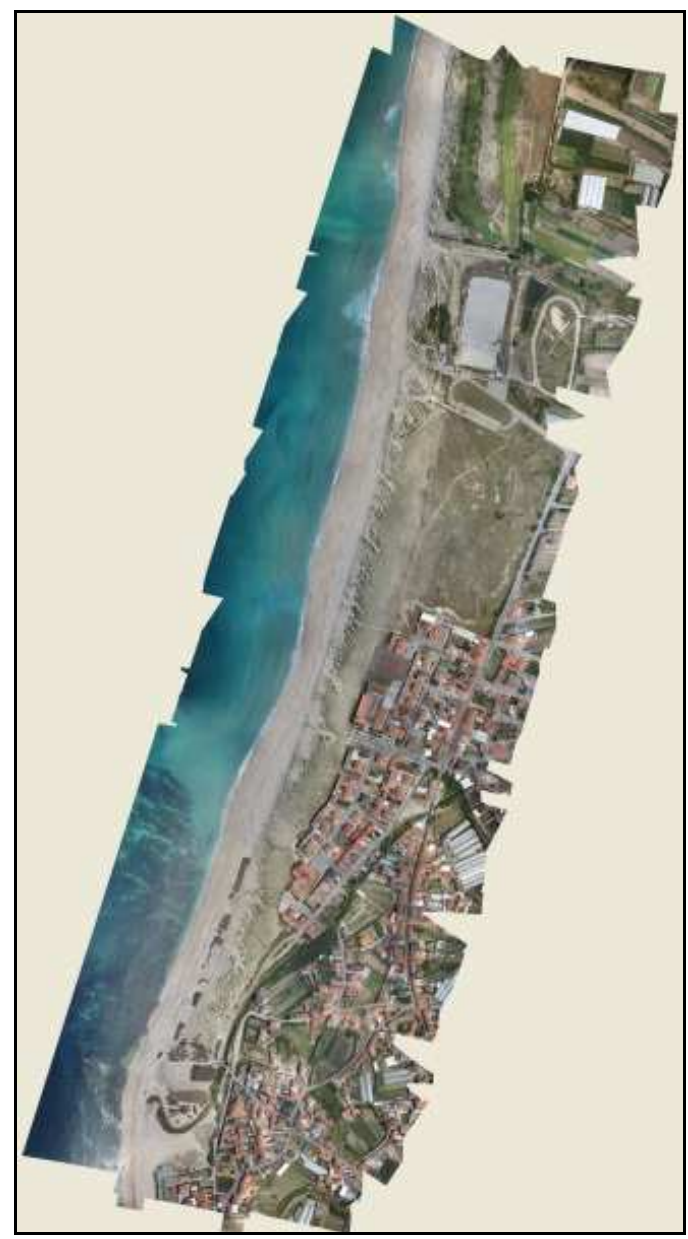

Figure 7. Orthophoto of the Aguçadoura beach (2014).

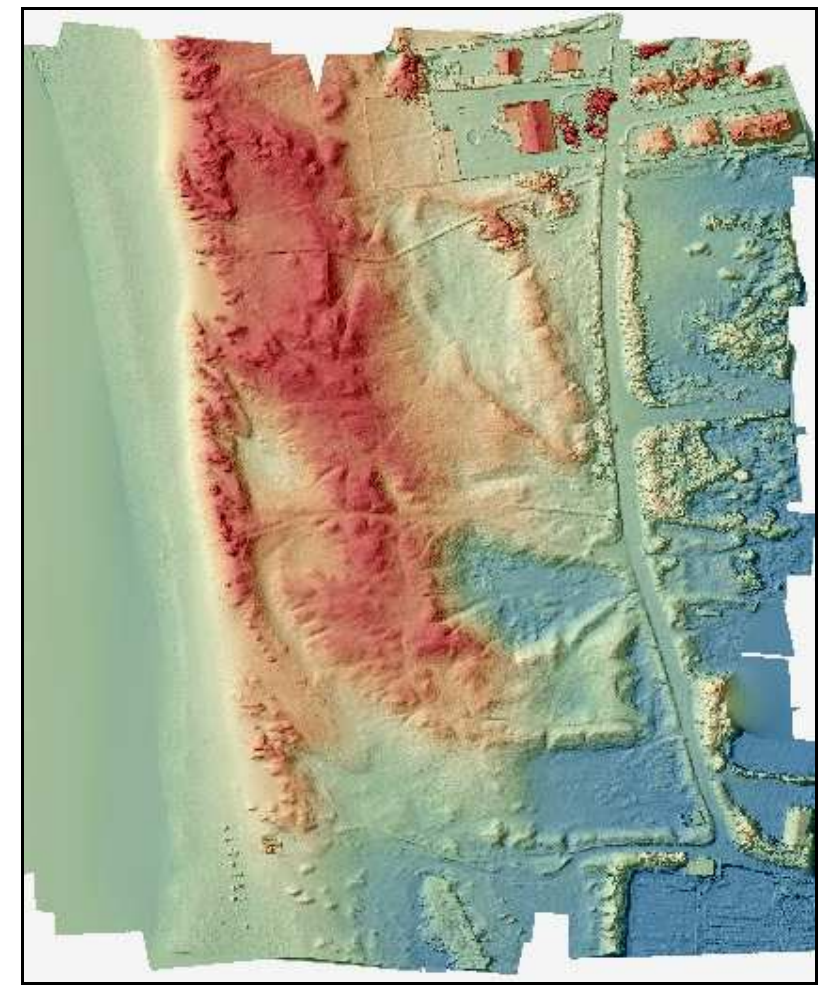

Figure 8. DEM of Ramalha beach (2014).

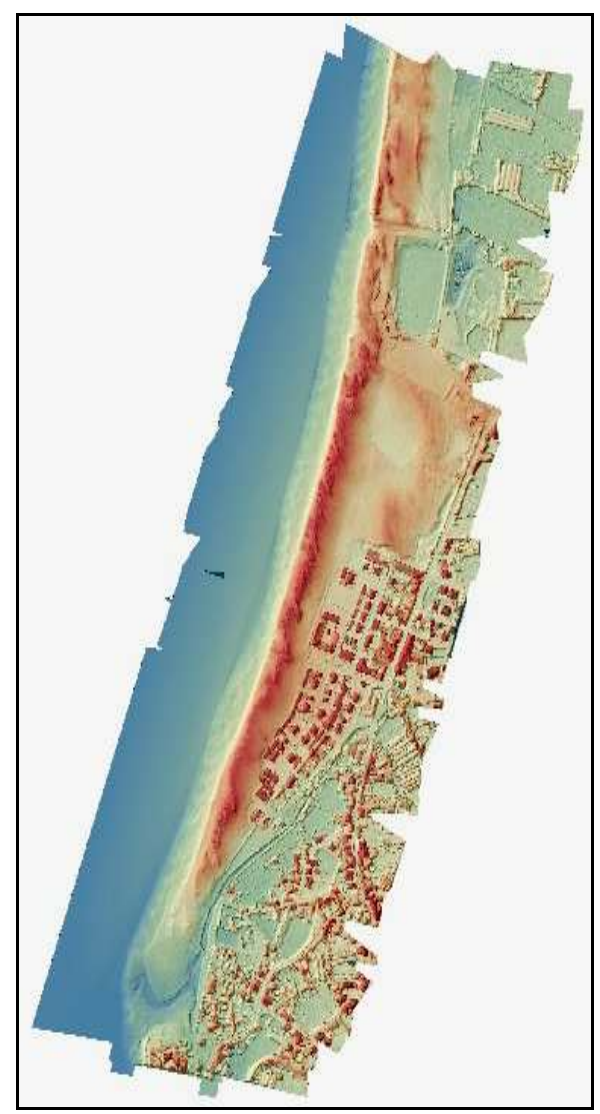

Figure 9. DEM of Aguçadoura beach (2014).

At this stage of study, we derived the above product without using the ground control points, or we used only the camera GPS data. For the case of Aguçadoura the accuracy of the altitude or the $\mathrm{z}$-value is 2.8 meters in average and that of the pixel is 0.6 in average (Figure 10). We visualized the models in the GISs software and checked the relief heights there. The same accuracies had the Ramalha beach models.

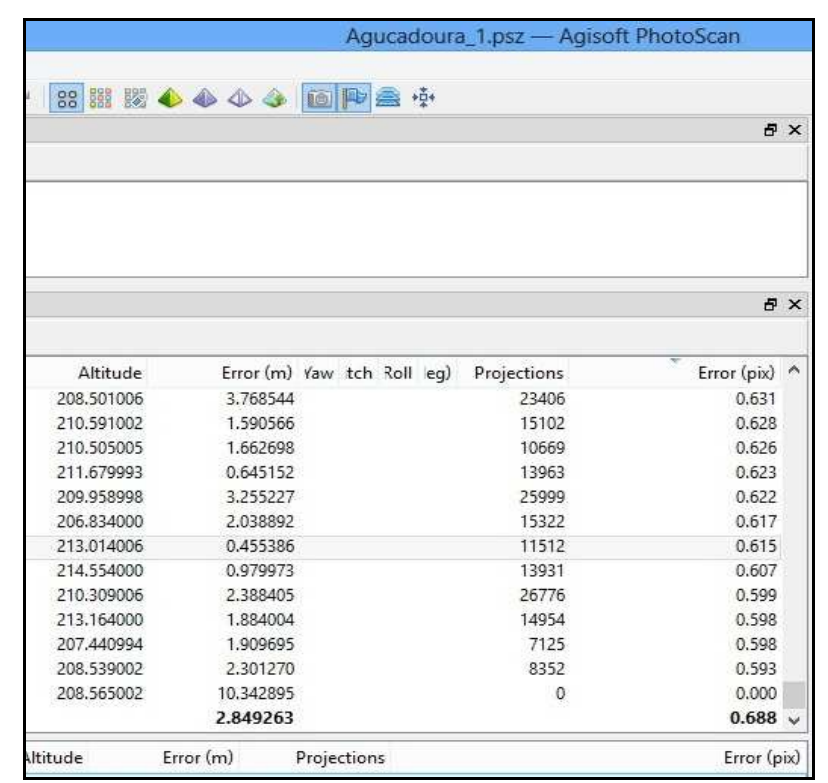

Figure 10. Extract of the workflow of the software Agisoft PhotoScanPro for Aguçadoura beach (2014). 


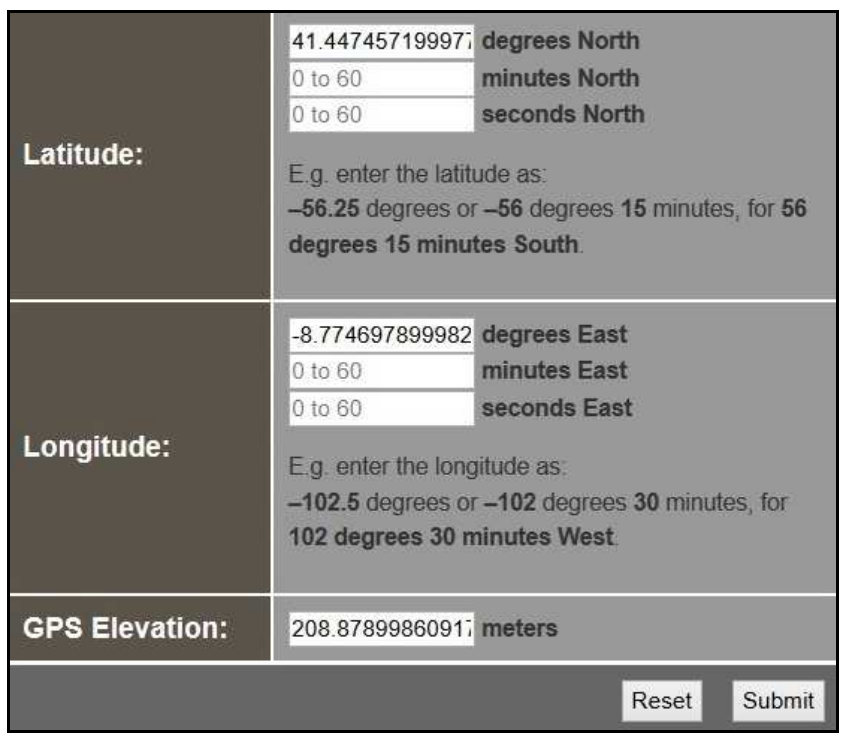

Figure 11. Earth Gravitational Model 1996 (EGM96).

The reason for that is related with the coordinate system used. The coordinates from the GPS in PT-TM06/ETRS86 have the national altimetry datum. The coordinates in WGS84 used without GCPs, have heights in a worldwide datum. That must be corrected to local heights with an Earth Gravitational Model 1996 (EGM96) [11].

To see how the model works, we input the camera GPS data of one of the images (Figure 11) with the corresponding coordinates and elevation. After calculation the model corrected the elevation only by about 56 meters, which is the geoid height (Figure 12). Therefore, the model is noticeably deformed in elevation ( $\mathrm{z}$ value) when compared to the real world terrain without GCP's.

Proceeding from above mentioned, our future goal is to conduct survey of the study area by using the Differential GPS in order to get better results regarding the elevation accuracies.

File Edit View History Bookmarks Iools Help
Q Ask.com
Your Input Coordinates and GPS Height:
Latitude $=41.4474571999775^{\circ} \mathrm{N}=41^{\circ} 26^{\prime} 50.85^{\prime \prime} \mathrm{N}$
Longitude $=8.7746978999822^{\circ} \mathrm{W}=8^{\circ} 46^{\prime} 28.91^{\prime \prime} \mathrm{W}$
GPS ellipsoidal height $=208.878998609179$ (meters)
Geoid height $=55.536$ (meters)
$\begin{aligned} & \text { Orthometric height (height above EGM96 geoid which approximates } \\ & \text { mean sea level) }=153.342998609179 \text { (meters) }\end{aligned}$
(note: orthometric height $=$ GPS ellipsoidal height - geoid height)

Figure 12. EGM96 calculation result.

\section{Conclusion}

We concluded that in case we would like to use the orthophoto to extract a bidimensional indicator of dynamics in coastal zone, such as the vegetation line, the accuracy achieved without using the ground control points (GCPs) is sufficient. However, to determine the coastal area profiles with correct local elevation, and to compile the large-scale maps of high resolution ( $\mathrm{z}$ value error: $1 \mathrm{~cm}-5 \mathrm{~cm}$ ), for monitoring and management of the geoecological state of the study area, it is necessary to take the precise coordinates by using the geodetic device of DGPS in the selected ground control points (GCP) and correct the derived $2 \mathrm{D}$ and $3 \mathrm{D}$ models of the study area.

\section{Acknowledgements}

We are grateful to the European Commission ERASMUS-MUNDUS Action-2 ELECTRA program and the Earth Sciences Centre of the University of Minho (Braga, Portugal) in supporting us to conduct the field works and research.

\section{References}

[1] L. Markelin. "Radiometric calibration, validation and correction of multispectral photogrammetric imagery". Publications of Finnish Geodetic Institute, No: 148. Tampere, 2013, p. 13.J. Clerk Maxwell, A Treatise on Electricity and Magnetism, 3rd ed., vol. 2. Oxford: Clarendon, 1892, pp.68-73.

[2] H. Eisenbeiss and M. Sauerbier. "Investigation of uav systems and flight modes for photogrammetric applications". The Photogrammetric Record, 26 (136): 400-421. doi: 10.1111/j.1477-9730.2011.00657.x. K. Elissa, "Title of paper if known," unpublished.

[3] J.A. Gonçalves and R. Henriques. "Uav photogrammetry for topographic monitoring of coastal areas". ISPRS Journal of Photogrammetry and Remote Sensing. Volume 104, 2015, pp.101-111.

[4] A. Bio, L.Bastos, H. Granja, J. L. S. Pinho, J. A. Gonçalves, R. Henriques, S.Madeira, A.Magalhães, D. Rodrigues. „Methods for coastal monitoring and erosion risk assessment: two Portuguese case studies“. Journal of Integrated Coastal Zone Management; 15(1):47-63. DOI: 10.5894/rgci490; 2015, pp.47-63.M. Young, The Technical Writer's Handbook. Mill Valley, CA: University Science, 198.

[5] "Portugal. II. Physical-geographical characteristics". Great Soviet Encyclopedia V.35, 2nd edition. Lead Editor B.A. Vvedensky. State Scientific Publishing House "Bolshaia sovetskaia entsiklopedyia", Moscow), 1955, p.200 (Portugalya. II. Fiziko-geografichesky ocherk (1955). Bolshaya sovetskaya enciklopedya. T. 35, II vipusk. Glavnyi redaktor B. A. Vvedensky. Gosudarstvennoe nauchnoe izdatelstvo "Bolshaia sovetskaia entsiklopedija”, Moskva, c. 200). (in Russian).

[6] J. P. F. Carvalho. "Coastal and dune systems rehabilitation The case of Quiaios-Mira coastal zone of Portugal". Ecological Engineering Applied to Environmental Restoration in Mediterranean Areas, CIHEAM, Zaragoza, Spain, June 7-18, 2004, p.1.

[7] H. M. Granja. „Evidence for Late Pleistocene and Holocene sea-level, neotectonic and climate control in the coastal zone of northwest Portugal“. Geologie en Mijnbouw (Impact Factor: 0.89), Volume 77, Issue3-4, 1998, p. 233. 

Area Geoecological Conditions (on the Example of Portugal)

[8] http://www.world66.com/europe/portugal/pvoa_de_varzim/be aches/aguadoura_beach

[9] http://www.playocean.net/en/portugal/esposende/beaches/prai a-da-ramalha-beach
[10] https://www.sensefly.com/operations/overview.html

[11] https://www.unavco.org/software/geodetic-utilities/geoid-heig ht-calculator/geoid-height-calculator.html. 